\title{
Рідкісні рослини природного заповідника «Михайлівська цілина»
}

\section{Ганна Клименко, Марина Шерстюк}

Сумський національний аграрний університет, м. Суми, Україна

Адреса для листування: annaklimenko2014@gmail.com

Отримано: 16.10.19; прийнято до друку: 20.12.19; опубліковано: 27.12.19

Резюме. Природний заповідник «Михайлівська цілина» розташований у Лебединському районі Сумської області на межиріччі річок Груні та Сули. У 1928 році заповідник отримав статус заповідника місцевого значення, а 1947 року на його основі було створено заповідник «Михайлівська цілина» загальнодержавного значення. Упродовж 1961-2009 pр. заповідник входив до складу Українського степового заповідника. У 2009 році він знову отримав самостійність. На сьогодні заповідник має площу 882,9 га, на частку абсолютної заповідності припадає 202,4 га. У заповіднику охороняється унікальний плакорний різнотравно-злаковий степ 3 домінуванням степових дерновинних злаків. Геоботанічне обстеження 1956 року показало, що в заповіднику переважають фітоценози з домінуванням дерновинних злаків, зокрема, Stipa capillata L., Festuca valesiaca Schleich. ex Gaudin, на невеликих ділянках домінантами виступали Stipa pennata L. або Stipa tirsa Steven. Саме ці типи рослинності є унікальною природною цінністю. У флорі природного заповідника «Михайлівська цілина» відбуваються помітні трансформації. Окремі види степових рослин зникають. Відбувається досить відчутне включення у фітоценози степу інвазійних видів рослин. Відзначається загальна мезофітизація флори, що проявляється через витіснення степових видів та їх заміщення лучними видами рослин.

Оскільки важливими біоіндикаторами стану флори і фітоценозів є рідкісні види рослин та їх популяції, наші дослідження були направлені саме на їх вивчення. Для оцінки екологічних амплітуд та екологічних оптимумів рідкісних видів рослин природного заповідника «Михайлівська цілина» ми використали екологічні шкали Я. П. Дідуха. Загальну стійкість окремого виду рослин до тієї чи іншої групи екологічних чинників оцінювали за допомогою індексу толерантності.

За рахунок вузького діапазону екологічних ніш до змін екологічних факторів на території заповідника «Михайлівська цілина» загалом найбільш чутливими є Pulsatilla patens (L.) Mill, Bulbocodium versicolor (Ker Gawl.) K.Perss., Adonis vernalis L. i Stipa tirsa Steven. Ці види можуть випадати зі складу його флори в першу чергу. Рідкісні рослини за відношенням до клімато-едафічних факторів формують три групи: стенобіонти, гемістенобіонти, мезобіонти. В умовах наростаючої мезофітизаціі рослинного покриву заповідника «Михайлівська цілина» в найбільшій небезпеці можуть опинитися три види рослин-стенобіонтів. У групі гемістенобіонтів найбільш уразливі Bulbocodium versicolor, Adonis vernalis i Stipa tirsa.

Ключові слова: природний заповідник «Михайлівська цілина», рідкісні види рослин, екологічні амплітуди, стійкість рослин.

\section{Rare Plants of the Mykhailivs'ka Tsilyna Nature Reserve.}

\section{Hanna Klymenko, Maryna Sherstiuk}

Sumy National Agrarian University, Sumy, Ukraine

Mailing address: annaklimenko2014@gmail.com

Abstract. The Mykhailivs'ka tsilyna Nature Reserve is located in the Lebedinsky district of Sumy region on the riverside of the Grun' and Sula rivers. In 1928, the Reserve received the status of a local important object of Nature Reserve Fund. In 1947, on its basis was created a Reserve of national importance "Mykhailivs'ka tsilyna". From 1961 to 2009, this object was a part of the Ukrainian Steppe Reserve. In 2009 he regained his independence. Presently, the reserve has an area of 882.9 hectares, the share of absolute reserve territori is 202.4 hectares. The reserve preserves a unique placor forbs-grasses step dominated by steppe turf grasses. A geobotanical survey in 1956 showed that the reserve was dominated by phytoceonoses with turf grasses, in 
particular, Stipa capillata L., Festuca valesiaca Schleich. ex Gaudin were dominance species. In small areas phytoceonoses dominated by Stipa pennata L. or Stipa tirsa Steven. These types of vegetation has unique natural value. There are noticeable transformations in the flora of the Mykhailivs'ka Tsilyna Nature Reserve. Some species of steppe plants disappear. There is quite a significant inclusion in the steppe phytocenoses of the invasive plant species. There is a general mesophytization of the flora, manifested by the displacement of the steppe species and their replacement by meadow species of plants.

Rare plant species and their populations are an important bioindicators of flora and phytocenoses. That is why our research has focused on their study. To estimate the ecological amplitudes and ecological optima of the rare plant species of the Mykhailivs'ka Tsilyna Nature Reserve, we used ecological scales of Ya. P. Diduch. The overall resistance of a particular plant species to one or another group of environmental factors was assessed using the tolerance index.

In general, Pulsatilla patens (L.) Mill, Bulbocodium versicolor (Ker Gawl.) K.Perss., Adonis vernalis L. and Stipa tirsa Steven. are the most sensitive to changes in environmental factors due to the narrow range of ecological niches within the territory of the Mykhailivs'ka Tsilyna Nature Reserve. These types of plants may fall out of its flora first. In general, rare plants in their relation to climate-edaphic factors are forming three groups: stenobionts, hemostenobionts, mesobionts. In the conditions of increasing mesophytization of the vegetation of the Mykhailivs'ka Tsilyna Nature Reserve, three types of stenobiont plants may be in greatest danger. Bulbocodium versicolor, Adonis vernalis and Stipa tirsa are the most vulnerable in the hemistenobionts group.

Key words: Mykhailivs'ka Tsilyna Nature Reserve, rare plant species, ecological amplitudes, plant resistance.

\section{ВСТУП}

Природний заповідник «Михайлівська цілина» має досить тривалу й складну історію [1-3]. Заповідник розташований у Лебединському районі Сумської області на межиріччі річок Груні і Сули. До 1918 року ця територія належала поміщику Капністу і iї використовували для випасу коней. Пізніше ця ділянка була передана Михайлівському кінському заводу, а в 1928 році отримала статус заповідника місцевого значення. У 1947 році на його основі було створено заповідник «Михайлівська цілина» загальнодержавного значення. Упродовж 1961-2009 pp. заповідник входив до складу Українського степового заповідника. У 2009 році він знову отримав самостійність.

Сьогодні заповідник має площу 882,9 га. На абсолютну заповідність припадає 202,4 га.

У заповіднику охороняється унікальний плакорний різнотравно-злаковий степ 3 домінуванням степових дерновинних злаків. Геоботанічне обстеження 1956 року показало, що в заповіднику переважають фітоценози 3 домінуванням дерновинних злаків, зокрема, Stipa capillata L., Festuca valesiaca Gaudin, на невеликих ділянках домінантами виступали Stipa pennata L. s. str. або Stipa tirsa Steven. Саме ці типи рослинності $\epsilon$ унікальною природною цінністю.

Але 3 плином часу сукцесійні процеси прийняли несприятливий характер. Послідовні геоботанічні дослідження 1971, 1981 і 1991 років показали, що в заповіднику стали збільшуватися площі 3 домінуванням кореневищних злаків Elytrigia repens (L.)
Nevski, Calamagrostis epigeios (L.) Roth, Arrhenatherum elatius (L.) J. Presl \& C. Presl. Активізувався процес загальної мезофітизації рослинності та ії олучнення. У травостій стали масово потрапляти і розвиватися лучні, лісові та болотні види. На ділянках абсолютної заповідності йшло активне поширення Urtica dioica L. Збільшилися площі, займані чагарником Chamaecytisus ruthenicus (Fisch. ex Woloszcz.) Klásk. Площі 3 домінуванням дерновинних степових злаків зменшилися до $16 \%$ від загальної території заповідника.

Загалом, за результатами аналізу даних моніторингу основних типологічних різновидів українських степів за період 1967-2012 рр. була виявлена загальна стійка тенденція до скорочення ксероморфної складової на $30 \pm 10 \%$ i збільшення мезоморфної (на $10 \pm 5 \%$ ) i

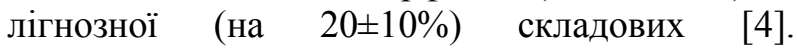
Заповідник «Михайлівська цілина» так само, як і інші степові ділянки України, став втрачати свою вихідну цінність.

На жаль, до сьогодні залишається дискусійним питання про те, що охороняти в заповідниках i які методи для цього використовувати. Я. П. Дідух [5] писав: «Вчені хочуть бачити в степу степові угруповання, а натуралісти -«дику природу». I далі: «Виникає дилема: чи повинні ми охороняти в заповідниках види та угруповання, заради яких створювали заповідник, або ж спостерігати за процесами змін, які призведуть до формування тривіальних чагарників, а далі лісових угруповань? Все ускладнюється ще й тим, що стадії формування чагарниково-лісових ценозів супроводжуються інвазією адвентивних видів 
(клена американського, ясена пенсильванського, робінії і т.д.)».

Фактично фахівці поки що не мають єдиної думки про можливість та ефективність застосування в конкретних умовах того чи іншого методу збереження степів - режиму абсолютної заповідності, регульованого випасу сільськогосподарських тварин або сінокосіння $[6,7]$. Це пов'язано з багатозначністю цільових функцій природних заповідних територій та суб'єктивністю їх тлумачення. Актуальним питанням $\epsilon$ й оптимізація територіальних ознак (показників площі, периметру та їхнього співвідношення) територій із природоохоронним статусом [8].

При оцінці стану рослинності та рослин на заповідних територіях і вибору методу охорони степу не слід упускати з виду, що режим заповідання захищає тільки від деяких прямих антропогенних впливів (випас, сінокосіння, розорювання, вирубка чагарників i дерев тощо). Водночас усі заповідники, зокрема й «Михайлівська цілина», відчувають вплив таких чинників, як глобальне потепління клімату, зміна кількості та періодичності випадання опадів, глибока трансформація фауни регіонів, яка змінюе доступність запилення для ентомофільних рослин, дисперсії діаспор у зоохорів, діяльність фітофагів та ін.

Одним із завдань заповідника «Михайлівська цілина» $€$ збереження біорізноманіття його степової флори. Флору природного заповідника «Михайлівська цілина» вивчали багато фахівців $[9,10]$, але грунтовно вона не вивчена. На сьогодні зареєстровано 493 види рослин. А. С. Родінка [11] відзначає наявність багатьох протиріч у даних про склад флори заповідника й навіть явних помилок.

Проте встановлено, що у флорі природного заповідника «Михайлівська цілина» відбуваються помітні трансформації. Деякі види степових рослин зникають. Наприклад, Astragalus dasyanthus Pall. протягом останніх років не реєструється, - мабуть, повністю випав із травостою [11]. Йде досить відчутна інвазія у фітоценози степу нехарактерних видів рослин. Багато дослідників відзначали загальну мезофітизацію флори, що виявляється у витісненні степових видів i їх заміщенні лучними видами рослин.

Актуальними завданнями для заповідника є: по-перше, ретельна флористична інвентаризація з повним установленням видів рослин, які зростають на його території; по-друге, моніторинг складу флори, якщо не щорічний, то, як мінімум, 3 інтервалом не менше 3-5 років. Тільки виконання цих двох завдань дозволить точно встановити тренди флористичного складу цієї цінної заповідної території України.

3 огляду на те, шо важливими біоіндикаторами стану флори і фітоценозів $\epsilon$ рідкісні види рослин i ïx популяції [12], основною метою роботи є оцінка екологічної амплітуди та екологічних оптимумів рідкісних видів рослин природного заповідника «Михайлівська цілина», визначення загальної стійкості рідкісних видів рослин до певної групи екологічних чинників.

\section{МАТЕРІАЛИ Й МЕТОДИ ДОСЛІДЖЕНЬ}

Для оцінки екологічних амплітуд та екологічних оптимумів рідкісних видів рослин природного заповідника «Михайлівська цілина» ми використали екологічні шкали Я. П. Дідуха [13], за якими наведені екологічні амплітуди для зазначеної групи рідкісних видів.

Для порівняльної стійкості окремих видів рослин природного заповідника «Михайлівська цілина» до комплексу екологічних чинників ми застосували методичні підходи Л. А. Жукової [14]. Загальна стійкість виду рослини до тієї чи іншої групи екологічних чинників в цьому випадку оцінюється індексом толерантності

$$
I t=\sum P E V / N
$$

де It - індекс екологічної толерантності, PEV потенційна екологічна амплітуда за екологічною шкалою, $\mathrm{N}$ - кількість використаних екологічних шкал.

У свою чергу

$$
P E V=\left(A_{\max }-A_{\min }+1\right) / \mathrm{n}
$$

де $\mathrm{A}_{\max } \mathrm{i} \mathrm{A}_{\min }$ - відповідно максимальне $\mathrm{i}$ мінімальне значення екологічної амплітуди за екологічною шкалою, $\mathrm{n}$ - кількість ступенів, на які поділяється ця шкала.

Значення індексу It, які не перевищують 0,33, відповідають видам рослин стенобіонтам за групою використовуваних екологічних факторів, значення 0,34-0,45 - видам гемістенобіонтам, 0,46-0,56 - мезобіонтам, 0,57-0,66 геміеврибіонтам, 0,67 і більше - еврибіонтам.

До аналізу для обчислення індексу кліматоедафічної толерантності видів рослин 
заповідника були залучені шість екологічних факторів: Hd - водний режим, $\mathrm{fH}$ - змінність режиму зволоження, Tm - терморежим, Om гумідність/аридність клімату, $\mathrm{Nt}$ - вміст азоту в грунті, Ае - аерація грунту.

\section{РЕЗУЛЬТАТИ ТА ЇХ ОБГОВОРЕННЯ}

У Сумській області зареєстровано та охороняється 150 видів судинних рослин [15]. У природному заповіднику «Михайлівська цілина» виявлено 15 видів рідкісних рослин, занесених до Червоної книги України [16], 3 яких 2 види занесені до списку МСОП, 1 вид до Червоного списку ЄС і 3 види - у Додаток до Бернської конвенції. Це такі види рослин:

1. Adonis vernalis L. Багаторічна трав'яниста рослина 3 товстим косогоризонтально розталованим кореневищем. Криптофіт. Розмножується генеративно і вегетативно. Мезоксерофіт. Світлолюбивий. Рослини горицвіту худоба не з'їдає. До сінокосіння він стійкий.

2. Astragalus dasyanthus Pall. Багаторічна стрижнекоренева трав'яниста рослина 20-30 см заввишки. Розмножується насінням. Ксерофіт.

Популяції зазвичай 3 низькою чисельністю особин, особливо в умовах випасу тварин. Зокрема, це пов'язано зі швидким пригніченням рослин при ущільненні грунту [17]. Ізольоване розташування популяцій i їх фрагментація часто виступають як основна причина випадання цього виду зі степових фітоценозів. Заготовляють як лікарську сировину.

3. Botrychium multifidum (S.G.Gmel) Rupr. Багаторічна трав'яниста рослина 3 коротким кореневищем 3 відділу папоротеподібних. Вайї (зазвичай їх дві) до 10 см завдовжки, зимуючі. Розмножується спорами i, можливо, вегетативно. На продукування спор негативно впливає низька кількість опадів у літній період [18]. Геофіт. Мезофіт.

Основними загрозами для виду $є$ випас худоби і випалювання травостою.

4. Bulbocodium versicolor (Ker-Gawl.) Spreng. Багаторічна цибулинна рослина. Заввишки до 15 см. Розмножується насінням і вегетативно. Популяції займають площу від декількох квадратних метрів до 25 га. Популяційна щільність коливається від 2-5 до 160 особин/м². Геофіт. Весняний ефемероїд. Мезофіт. Витримує температуру до $-34^{\circ} \mathrm{C}$. Погано переносить випас худоби.

5. Dactylorhiza majalis (Rchb.) R.F.Hunt et Sum. Багаторічна трав'яниста рослина заввишки 15-60 см 3 двома пальчатороздільними бульбами. Мезогігрофіт.
Цей вид, як і багато європейських видів пальчатокорінника, має гібридне походження i $€$ стабільним аллотетраплоїдом, що виникли внаслідок гібридизації пальчатокорінника Фукса (D.fuchsii) i 'ясо-червоного (D. incarnata).

Як у багатьох орхідних, життєвий стан рослин залежить від можливості формувати повноцінну мікоризу [19].

6. Dracocephalum ruischiana L. Багаторічна кореневищна рослина висотою 40-60 см. Розмножується насінням i вегетативно. Ентомофіл. Гемікриптофіт.

7. Fritillaria ruthenica Wilkstr. Тра'янистий цибулинний полікарпік $15-70$ см заввишки. Ефемероїд. Розмножується насінням i вегетативно, утворюючи дочірні цибулини i додаткові виводкові бруньки.

У природних популяціях Fritillaria ruthenica насіннєва продуктивність досягає 74-81 шт. насінин в одному плоді, частка виповненого насіння складає 82\%. Маса 1000 шт. насінин варіює від 1,65 до 2,25 г [20]. Рослина погано переносить випалювання травостою, випас худоби та ущільнення грунту. Мезофіт.

8. Gladiolus tenuis M. Bieb. Багаторічна трав'яниста рослина 30-70 см заввишки. Бульбоцибулина куляста, 1-1,5 см. в діаметрі. Розмноження насіннєве i вегетативне за допомогою цибулинок - діток. Стенотоп зі слабкою конкурентною здатністю. Мезофіт, сціогеліофіт.

Популяції $G$. tenuis в умовах заплавних лук p. Псел мають повночленні лівосторонні спектри та високі показники індексу відновлення. Проте частка генеративних рослин знижується 3 44,79\% на луках, які не викошують, до $23,40-24,60 \%$ на сінокісних ділянках. Досліджувані популяції за різними класифікаціями належать до інвазійного та молодого типів [21].

9. Iris pineticola Klokov. Багаторічник 3 товстим повзучим довгим кореневищем. Стебло 10-20 см заввишки. Розмножується насінням i вегетативно. Кріптофіт. Мезоксерофіт.

Вид тяжіє до незімкнутих відкритих степових псамофітних угруповань, в яких досягає максимальної рясності при загальному проективному покритті 45-50\%, і є в них ценофобом та ерозіофілом. У популяціях за сприятливих умов переважають віргінільні й генеративні особини [22].

10. Pulsatilla patens (L.) Mill. s.1. Багаторічна тра'яниста рослина 3 потужним вертикальним багатоголовим кореневищем. Морфометричні 
Рідкісні рослини природного заповідника «Михайлівська иілина»

параметри рослин сильно варіюють залежно від умов місця зростання [23]. Розмножується насінням, але засвідчені випадки й вегетативного розмноження. В оптимальних умовах добре відновлюється завдяки високій насіннєвій продуктивності.

11. Pulsatilla pratensis (L.) Mill. s.1. Багаторічна трав'яниста рослина 10-40 см заввишки 3 товстим, вертикальним кореневищем i прямостоячим, одноквітковим, густом'яковолосистим, напіврозеточним стеблом.

Розмножується насінням. Насіннєва продуктивність варіює від 248 шт. (у природній популяції) до 6355 шт. насінин (на колекційній ділянці) [24]. У сухих степах насіннєве розмноження Pulsatilla pratensis різко знижується порівняно 3 лучними і сосновими фітоценозами [25].

Фітоценотична амплітуда Pulsatilla pratensis широка (Куземко та ін., 2014). Чисельність особин у популяціях велика, але сама кількість популяцій упродовж останніх десятиліть має тенденцію до скорочення.

Субмезофіт, субаерофіт, субацидофіл, мезотроф, акарбонатофіл і гемінітрофіл [26]. Морозостійкий до мінус $29^{\circ} \mathrm{C}$.

12. Stipa capillata L. Багаторічна трав'яниста рослина 40-80 см заввишки, що утворює щільні дерновини. Розмножується насінням. Популяції численні, повночленні, займають площу до сотень квадратних метрів, насіннєве поновлення на заповідних територіях стабільне.

Морозостійкий до мінус $18^{\circ} \mathrm{C}$. Світлолюбний, посухостійкий. Гемікриптофіт. Відзначається пригнічення при високих пасовищних навантаженнях.

13. Stipa pennata L. Трав'яниста щільнодерновинна багаторічна рослина. Найвищий вид ковили: його прямостоячі стебла і листя можуть досягати 1 м.

Розмножується насінням. Посухостійкий. Морозостійкий до мінус $23^{\circ} \mathrm{C}$. Світлолюбний.

14. Stipa tirsa Steven. Багаторічна трав'яниста щільнодерновинна рослина висотою 40-80 (до 100) см. Розмножується насінням. Гемікриптофіт. Найбільш мезофільний вид ковили. Один із найбільш чутливих до стравлювання i витоптування серед них. Негативно реагує на випас худоби.

15. Vincetoxicum rossicum (Kleopow) Barbar. Багаторічна трав'яниста рослина висотою 60$120 \mathrm{~cm}$.

Плід - загострена на верхівці листівка до $6 \mathrm{~cm}$ завдовжки, насіння 3 чубчиком. Трапляється рідко, утворює невеликі за площею популяції.
Особливості екології та популяційної структури цих рідкісних видів рослин в умовах природного заповідника «Михайлівська цілина» не встановлені. Наведений огляд, зроблений на основі літературних даних (та інших джерел), показує, що рідкісні види, які ростуть на території «Михайлівської цілини», вивчені недостатньо. Відносно цих видів та їх локальних популяцій на інших територіях $€$ тільки загальна інформація. Необхідним і важливим завданням $є$ вивчення екології цих видів і встановлення основних популяційних характеристик.

Актуальним завданням $є$ вивчення статусу популяцій цих видів рослин, оцінка їх біологічних та екологічних властивостей i чинників, які негативно діють на них. На необхідність пріоритетної охорони рідкісних видів рослин неодноразово вказували фахівці України [16, 27 і багато інших].

Стійкість популяцій рідкісних видів рослин у фітоценозах природного заповідника «Михайлівська цілина» в умовах зміни клімату i викликаних цими змінами сукцесійних процесів насамперед залежить від ширини їх екологічних амплітуд за основними кліматичними та едафічними факторами.

Екологічні амплітуди для цієї групи рідкісних видів представлено в табл. 1. Дані щодо екологічної приуроченості Gladiolus tenuis, Iris pineticola i Vincetoxicum rossicum в таблицях Я.П. Дідуха не наведені. Цей факт свідчить про слабку вивченість рідкісних рослин природного заповідника «Михайлівська цілина».

Екологічні оптимуми розглянутих рідкісних видів у зіставленні 3 їх екологічними амплітудами представлені на рис. 1-6.

Отриманий матеріал дозволив провести порівняльний аналіз екології рідкісних видів рослин заповідника і встановити для кожного 3 них екологічний фактор, який може виявитися критичним і лімітуючим при зміні екологічних умов фітоценозів.

Відносно режиму зволоження уразливими насамперед можуть виявитися Pulsatilla pratensis і в дещо меншій мірі Pulsatilla patens, екологічні амплітуди яких за цим фактором найвужчі (рис. 1).

При зміні кислотності грунту найвужчими екологічними амплітудами відрізняються Pulsatilla patens i Bulbocodium versicolor (рис. 2).

Азотний режим грунту не є критичним для цієї групи рідкісних рослин. Їх екологічні амплітуди за цим фактором досить широкі (рис. 3). 


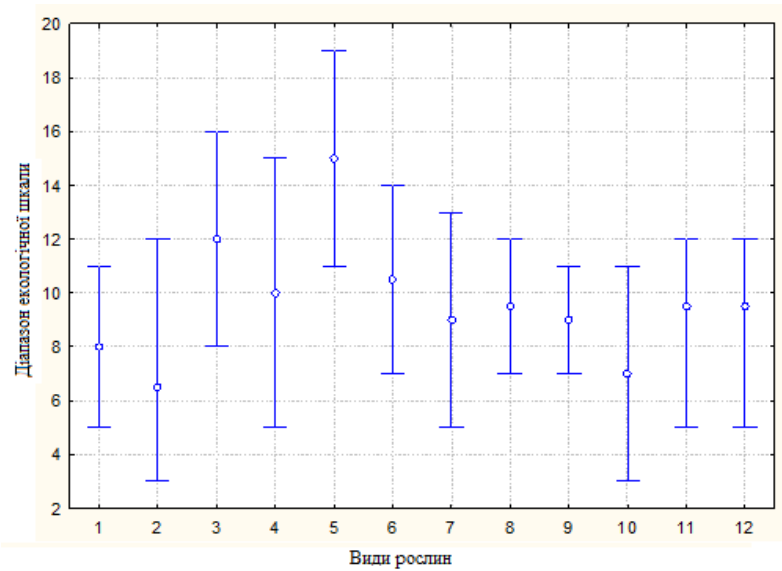

Рис. 1. Екологічні амплітуди та екологічні оптимуми рідкісних видів рослин природного заповідника «Михайлівська иілина» за икалою Hd-водний режим трунту. 1 - Adonis vernalis

L., 2 - Astragalus dasyanthus Pall., 3 -

Botrychium multifidum (S.G.Gmel) Rupr., 4 Bulbocodium versicolor (Ker-Gawl.) Spreng., 5 Dactylorhiza majalis (Rchb.) R.F.Hunt et Sum., 6 - Dracocephalum ruischiana L., 7 - Fritillaria ruthenica Wilkstr., 8 - Pulsatilla patens (L.) Mill.

s.1., 9 - Pulsatilla pratensis (L.) Mill. s.1., $10-$

Stipa capillata L., 11 - Stipa pennata L. s. str., 12 - Stipa tirsa Steven.

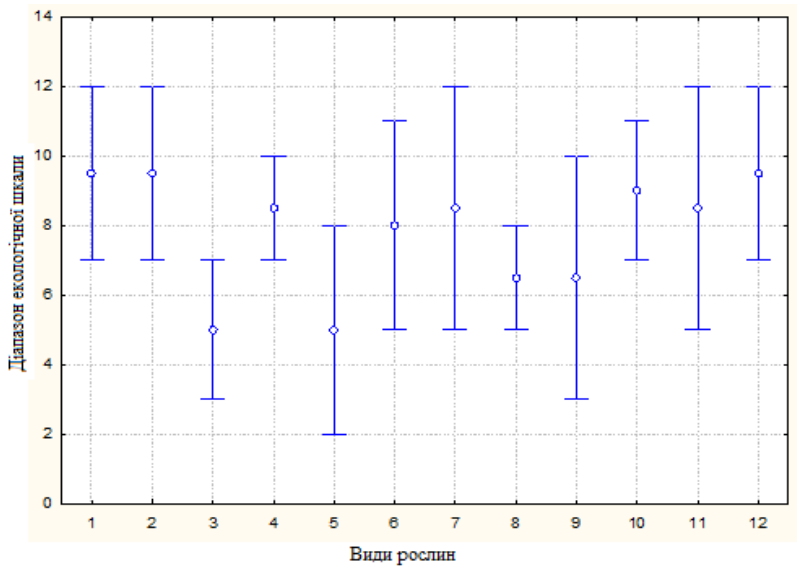

Рис. 2. Екологічні амплітуди та екологічні оптимуми рідкісних видів рослин природного заповідника «Михайлівська иілина» за икалою Rc - кислотність грунту. 1 - Adonis vernalis L., 2 - Astragalus dasyanthus Pall., 3 - Botrychium multifidum (S.G.Gmel) Rupr., 4 - Bulbocodium versicolor (Ker-Gawl.) Spreng., 5 -Dactylorhiza majalis (Rchb.) R.F.Hunt et Sum., 6 -

Dracocephalum ruischiana L., 7 - Fritillaria ruthenica Wilkstr., 8 - Pulsatilla patens (L.) Mill. s.1., 9 - Pulsatilla pratensis (L.) Mill. s.1., $10-$ Stipa capillata L., 11 - Stipa pennata L. s. str., 12 - Stipa tirsa Steven.

Таблицяя 1

Екологічні амплітуди рідкісних видів рослин природного заповідника «Михайлівська цілина»

\begin{tabular}{|c|c|c|c|c|c|c|c|c|c|}
\hline \multirow{2}{*}{ Види рослин } & $\mathrm{Hd}$ & $\mathrm{fH}$ & $\mathrm{Rc}$ & $\mathrm{Sl}$ & $\mathrm{Nt}$ & $\mathrm{Ae}$ & $\mathrm{Tm}$ & $\mathrm{Om}$ & $\mathrm{Lc}$ \\
\hline & \multicolumn{9}{|c|}{ Min / Max } \\
\hline Adonis vernalis & $3 / 12$ & $5 / 8$ & $7 / 12$ & $5 / 11$ & $3 / 7$ & $3 / 7$ & $7 / 12$ & $10 / 13$ & $7 / 9$ \\
\hline Astragalus dasyanthus & $5 / 11$ & $5 / 8$ & $7 / 12$ & $5 / 12$ & $3 / 6$ & $6 / 8$ & $8 / 11$ & $10 / 12$ & $7 / 9$ \\
\hline Botrychium multifidum & $8 / 16$ & $4 / 7$ & $3 / 7$ & $2 / 7$ & $1 / 7$ & $4 / 7$ & $4 / 9$ & $12 / 15$ & $4 / 7$ \\
\hline $\begin{array}{l}\text { Bulbocodium } \\
\text { versicolor }\end{array}$ & $5 / 15$ & $4 / 8$ & $7 / 10$ & $6 / 10$ & $3 / 6$ & $4 / 6$ & $9 / 14$ & $8 / 11$ & $6 / 9$ \\
\hline Dactylorhiza majalis & $11 / 19$ & $3 / 6$ & $2 / 8$ & $3 / 8$ & $2 / 8$ & $7 / 12$ & $4 / 10$ & $11 / 18$ & $4 / 9$ \\
\hline $\begin{array}{l}\text { Dracocephalum } \\
\text { ruischiana }\end{array}$ & $7 / 14$ & $4 / 7$ & $5 / 11$ & $5 / 9$ & $2 / 7$ & $5 / 8$ & $4 / 12$ & $11 / 14$ & $5 / 8$ \\
\hline Fritillaria ruthenica & $5 / 13$ & $6 / 9$ & $5 / 12$ & $6 / 11$ & $2 / 8$ & $5 / 8$ & $7 / 11$ & $7 / 13$ & $6 / 9$ \\
\hline Gladiolus tenuis & - & - & - & - & - & - & - & - & - \\
\hline Iris pineticola & - & - & - & - & - & - & - & - & - \\
\hline Pulsatilla patens & $7 / 12$ & $2 / 5$ & $5 / 8$ & $3 / 7$ & $2 / 6$ & $4 / 7$ & $5 / 11$ & $9 / 14$ & $6 / 9$ \\
\hline Pulsatilla pratensis & $7 / 11$ & $2 / 5$ & $3 / 10$ & $2 / 9$ & $2 / 6$ & $4 / 7$ & $7 / 10$ & $12 / 15$ & $6 / 9$ \\
\hline Stipa capillata & $3 / 11$ & $4 / 9$ & $7 / 11$ & $5 / 13$ & $2 / 7$ & $4 / 7$ & $6 / 13$ & $5 / 14$ & $7 / 9$ \\
\hline Stipa pennata & $5 / 12$ & $4 / 9$ & $5 / 12$ & $6 / 10$ & $3 / 7$ & $4 / 7$ & $7 / 12$ & $9 / 14$ & $7 / 9$ \\
\hline Stipa tirsa & $5 / 12$ & $4 / 9$ & $7 / 12$ & $6 / 11$ & $3 / 8$ & $4 / 7$ & $9 / 12$ & $10 / 12$ & $7 / 9$ \\
\hline Vincetoxicum rossicum & - & - & - & - & - & - & - & - & - \\
\hline
\end{tabular}

Примітка. $\mathrm{Hd}$ - водний режим грунту, $\mathrm{fH}$ - змінність режиму зволоження, Rc - кислотність трунту, Sl - сольовий режим трунту, Nt - вміст азоту в трунті, Ае - аерація трунту, Tm-терморежим, Om - гумідність / аридність клімату, Lc-освітленість. 


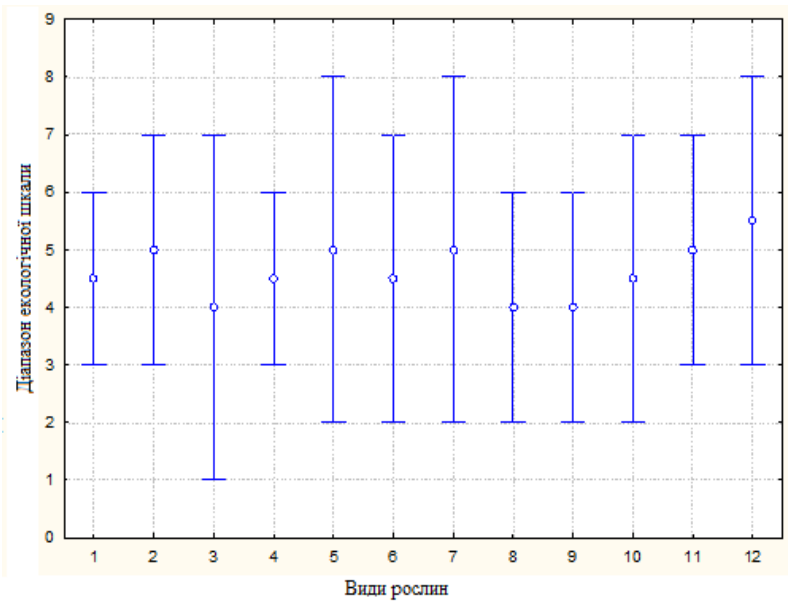

Рис. 3. Екологічні амплітуди та екологічні оптимуми рідкісних видів рослин природного заповідника «Михайлівська иілина» за шкалою $N t$ - вміст азоту в грунті. 1 - Adonis vernalis

L., 2 - Astragalus dasyanthus Pall., 3 -

Botrychium multifidum (S.G.Gmel) Rupr., 4 Bulbocodium versicolor (Ker-Gawl.) Spreng., 5 Dactylorhiza majalis (Rchb.) R.F.Hunt et Sum., 6 - Dracocephalum ruischiana L., 7 - Fritillaria ruthenica Wilkstr., 8 - Pulsatilla patens (L.) Mill. s.1., 9 - Pulsatilla pratensis (L.) Mill. s.1., 10 Stipa capillata L., 11 - Stipa pennata L. s. str., 12 - Stipa tirsa Steven.

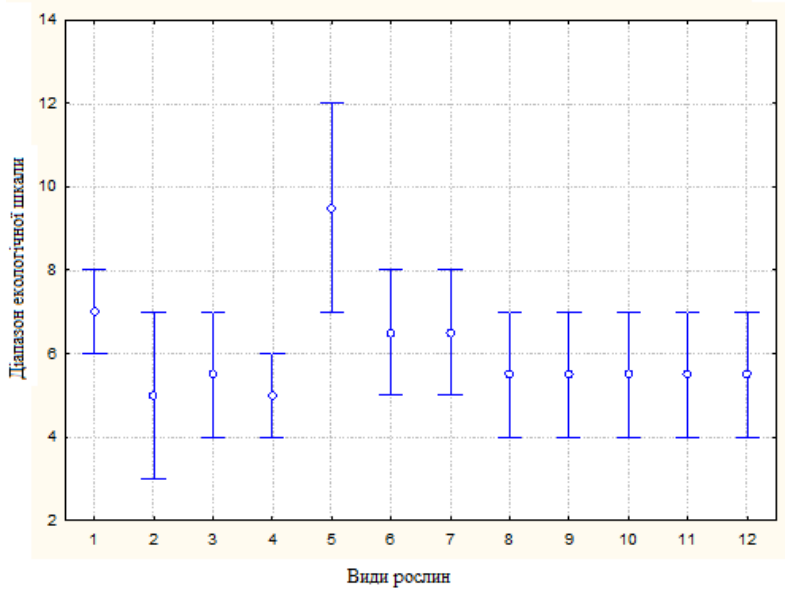

Рис. 4. Екологічні амплітуди та екологічні оптимуми рідкісних видів рослин природного заповідника «Михайлівська иілина» за шкалою Ae - аераиія грунту. 1 - Adonis vernalis L., 2 -

Astragalus dasyanthus Pall., 3 - Botrychium multifidum (S.G.Gmel) Rupr., 4 - Bulbocodium versicolor (Ker-Gawl.) Spreng., 5 - Dactylorhiza majalis (Rchb.) R.F.Hunt et Sum., 6 -

Dracocephalum ruischiana L., 7 - Fritillaria ruthenica Wilkstr., 8 - Pulsatilla patens (L.) Mill. s.1., 9 - Pulsatilla pratensis (L.) Mill. s.1., 10 Stipa capillata L., 11 - Stipa pennata L. s. str., 12 - Stipa tirsa Steven.

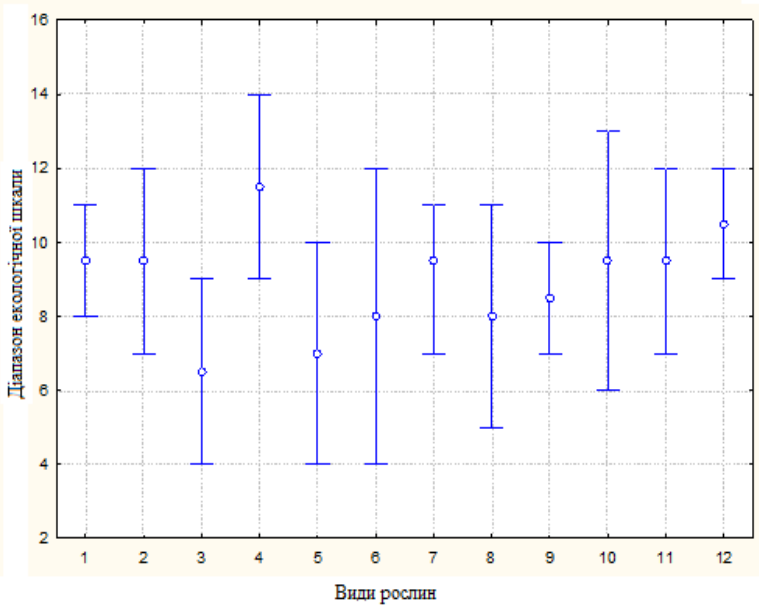

Рис. 5. Екологічні амплітуди та екологічні оптимуми рідкісних видів рослин природного заповідника «Михайлівська цілина» за шкалою Tm- терморежим. 1 - Adonis vernalis L., 2 -

Astragalus dasyanthus Pall., 3 - Botrychium multifidum (S.G.Gmel) Rupr., 4 - Bulbocodium versicolor (Ker-Gawl.) Spreng., 5 - Dactylorhiza majalis (Rchb.) R.F.Hunt et Sum., 6 -

Dracocephalum ruischiana L., 7 - Fritillaria ruthenica Wilkstr., 8 - Pulsatilla patens (L.) Mill. s.1., 9 - Pulsatilla pratensis (L.) Mill. s.1., 10 Stipa capillata L., 11 - Stipa pennata L. s. str., 12 - Stipa tirsa Steven.

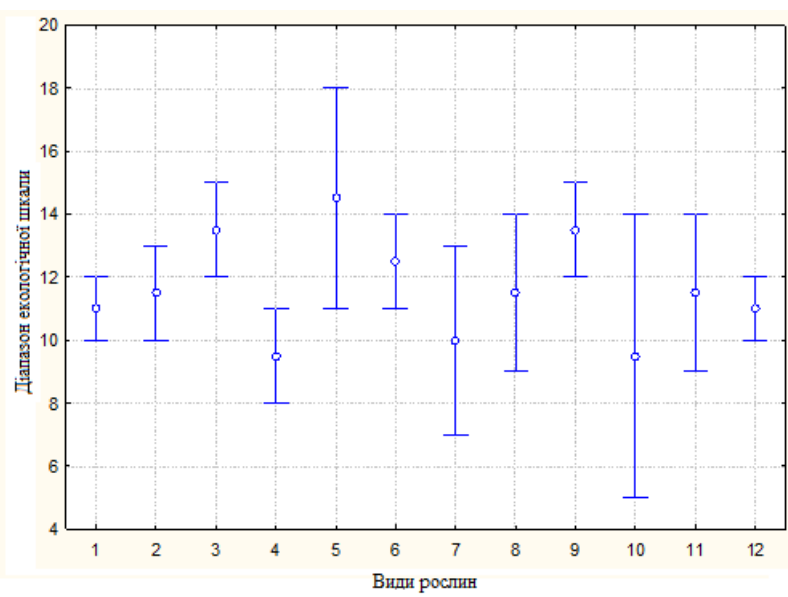

Рис. 6. Екологічні амплітуди та екологічні оптимуми рідкісних видів рослин природного заповідника «Михайлівська цұілина» за шккалою

От-гумідність / аридність клімату. 1 -

Adonis vernalis L., 2 - Astragalus dasyanthus Pall., 3 - Botrychium multifidum (S.G.Gmel) Rupr., 4 - Bulbocodium versicolor (Ker-Gawl.) Spreng., 5 -Dactylorhiza majalis (Rchb.) R.F.Hunt et Sum., 6 - Dracocephalum ruischiana

L., 7 - Fritillaria ruthenica Wilkstr., 8 Pulsatilla patens (L.) Mill. s.l., 9 - Pulsatilla pratensis (L.) Mill. s.1., 10 - Stipa capillata L., 11 - Stipa pennata L. s. str., 12 - Stipa tirsa Steven. 
Науковий вісник Східноєвропейського національного університету імені Лесі Українки. Серія: Біологічні науки, 2019, 4 (388)

Зміни режиму аерації грунтів заповідника може виявитися несприятливим фактором передусім для таких видів рослин, як Bulbocodium versicolor i Adonis vernalis. Найменш чутлива рослина до цього фактору Dactylorhiza majalis (рис. 4).

До змін температурного режиму рідкісні види природного заповідника «Михайлівська цілина» мало чутливі. Винятком є лише Stipa tirsa (рис. 5).

Найбільш чутливі до змін режиму аридності/ гумідності клімату Adonis vernalis та Stipa tirsa (рис. 6).

Загалом, за рахунок вузького діапазону екологічних ніш до змін екологічних умов на території заповідника «Михайлівська цілина» найбільш чутливими є Pulsatilla patens, Bulbocodium versicolor, Adonis vernalis i Stipa tirsa. Ці види рослин можуть випадати зі складу його флори в першу чергу.

Збереження популяцій рідкісних видів рослин в умовах мезофітизації угруповань i загострення конкуренції 3 інвазійними видами вищі тоді, коли ширші екологічні амплітуди конкретного виду рослин за комплексом основних екологічних факторів. Пряме зіставлення екологічних амплітуд неможливе, тому що кількість ступенів шкали за різними екологічними режимами не однакова.

Наприклад, у Stipa tirsa ширина екологічної амплітуди за водним режимом грунту становить 8 одиниць $(12-5+1=8)$, а за вмістом азоту в грунті - 6 одиниць $(8-3+1=6)$. Складається враження, що за відношенням до азоту цей вид $є$ більш вразливим, ніж за відношенням до вологості, оскільки його екологічна амплітуда за вмістом азоту менш широка. Але шкала водного режиму грунту має 23 ступені, а шкала вмісту азоту - 11 ступенів. Таким чином, екологічна амплітуда цього виду рослин охоплює 34,7\% шкали вологості і 54,5\% шкали вмісту азоту в грунті. А отже, для Stipa tirsa зміни водного режиму грунту небезпечніші, ніж коливання вмісту в грунті азоту.

Для порівняльної стійкості окремих видів рослин природного заповідника «Михайлівська цілина» до комплексу екологічних чинників доцільно застосовувати методичні підходи Л. А. Жукової [14]. Значення цього індексу наведені на графіку (рис. 7).

Видно, що вивчені рослини за їхнім відношення до кліматично-едафічних факторів формують три групи:

1. Стенобіонти - Astragalus dasyanthus, Pulsatilla pratensis i Pulsatilla patens,
2. Гемістенобіонти - найбільш численна група, в яку входять Adonis vernalis, Botrychium multifidum, Bulbocodium versicolor, Dactylorhiza majalis, Dracocephalum ruischiana, Fritillaria ruthenica, Stipa pennata i Stipa tirsa.

3. Мезобіонти - цю групу представляє тільки один вид Stipa capillata.

В умовах наростаючої мезофітизації рослинного покриву заповідника «Михайлівська цілина» в найбільшій небезпеці опиняться три види рослин-стенобіонтів. У групі гемістенобіонтів найбільш уразливі Bulbocodium versicolor, Adonis vernalis i Stipa tirsa.

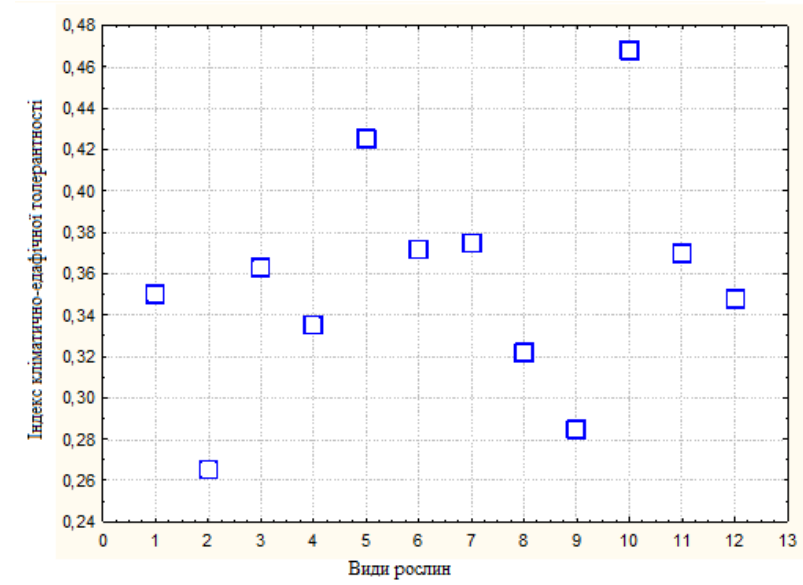

Рис. 7. Значення індексу кліматичноедафічної толерантності для рідкісних видів природного заповідника «Михайлівська изілина». 1 - Adonis vernalis L., 2 - Astragalus dasyanthus Pall., 3 - Botrychium multifidum (S.G.Gmel) Rupr., 4 -Bulbocodium versicolor (Ker-Gawl.) Spreng., 5 - Dactylorhiza majalis (Rchb.)

R.F.Hunt et Sum., 6 - Dracocephalum ruischiana

L., 7 - Fritillaria ruthenica Wilkstr., 8 -

Pulsatilla patens (L.) Mill. s.1., 9-Pulsatilla pratensis (L.) Mill. s.1., 10 - Stipa capillata L., 11 - Stipa pennata L. s. str., 12 - Stipa tirsa Steven.

\section{ВИСНОВКИ}

У геоботанічній літературі роботами багатьох дослідників показано, що стійкість видів рослин в тих чи інших мінливих умовах визначається не тільки їх екологією, а й структурою їх популяцій [28-30]. Тому подальшим актуальним завданням $є$ вивчення популяційної структури рідкісних видів рослин природного заповідника «Михайлівська цілина» - чисельності особин в локальних популяціях, популяційної щільності, віталітету особин, віталітетної та онтогенетичної структури їх популяцій. 
3 15-ти рідкісних видів рослин, що знаходяться під охороною на території природного заповідника «Михайлівська цілина», 12 видів запилюються комахами, тому для їхнього сталого існування необхідна підтримка різноманітності й достатньої чисельності ентомофауни. Фахівці із созології повинні прискорити розробку ефективних режимів, тим самим забезпечити збереження степових екосистем природного заповідника «Михайлівська цілина».

\section{ЛІТЕРАТУРА}

1. Білик, Г. I. Рослинність заповідника «Михайлівська цілина» та ii зміни під впливом господарської діяльності людини. Украӥнський ботанічний журнал; 1957, 14 (4), с 26-39.

2. Ткаченко, В. С.; Генов, А. П.; Лисенко, Г. М. Структура рослинності заповідного степу «Михайлівська цілина» за данними крупномасштабного картування в 1991 р. Украӥнсь-кий ботанічний журнал; 1993, 50 (4), с 5-18.

3. Лысенко, Г.Н.; Коротченко, И. А. Синтаксономические изменения растительного покрова луговой степи заповедника «Михайловская целина» (Сумская область, Украина). Растительность России; 2006, 9, с 43-57.

4. Ткаченко, В. С. Детерминировано природой. Степной бюллетень; 2014, 40, с 5-8.

5. Дидух, Я. П. Что мы должны охранять в степных заповедниках? Степной бюллетень; 2014, 40, c $8-11$.

6. Лысенко, Г.Н. Степные заповедники и абсолютно заповедный режим: поиски компромисса. Степной бюллетень; 2014, 40, с 11-16.

7. Борейко, В. Е.; Бриних, В. А.; Парникоза, И. Ю. Критика сенокошения и иных регуляционных мероприятий на степных и других территориях строгого природоохранного режима (категория I-A MCOП/IUCN); Логос: Киев, 2017; с 136.

8. Скляр, В. Г.; Скляр, Ю. Л. Системний підхід до оптимізації охорони природних комплексів. Украӥнський ботанічний журнал; 2003, 60 (4), с 388-396.

9. Парахонська, Н. О.; Ткаченко, В. С. Зміни флористичного складу Михайлівської цілини в умовах заповідності. Украйнський ботанічний журнал; 1984, 41 (5), с 13-16.

10. Ткаченко, В. С.; Дідух, Я. П.; Генов, А. П.; Дудка I. О.; Вассер, С. П. Український природний степовий заповідник. Рослинний світ. Фітосоціоцентр: Київ, 1998; с 280.

11. Родінка, О.С. Флористичні зміни у заповіднику «Михайлівська цілина» та їх причини. Природничі науки; 2014, 11, с 52-57.

12. Злобин, Ю. А.; Скляр, В. Г.; Клименко, А. А. Популяиии редких видов растений: теоретические основы и методика изучения; Университетская книга: Сумы, 2013, с 439.
13. Didukh, Ya. P. The ecological scales for the species of Ukrainian flora and their use in synphytoindication; Phytosociocentre: Kyiv, 2011; p 176.

14. Жукова, Л. А. Экологические шкаль и методика анализа экологического разнообразия растений; Йошкар-Ола, 2010; с 368.

15. Перегрим, М. М.; Андрієнко, Т. Л. Переліки регіонально рідкісних рослин адміністративних територій та природних регіонів України. Український ботанічний журнал; 2014, 71 (3), c 286-295.

16. Червона книга України. Рослинний світ; за ред. Я. П. Дідуха; Глобалконсалтинг: Киї, 2009, c 900 .

17. Zakharov, V. L.; Petrishheva, T. J.; Morgachjova, N. V. Rare Vascular Plant Species in the Lipetsk Region: Vital Status Assessment. EurAsian Journal of BioSciences; 2017, 11, p 78-84.

18. Mesipuu, M.; Shefferson, R.; Kull, T. Weather and herbivores influence fertility in the endangered fern Botrychium multifidum (S.G. Gmel.) Rupr. Plant Ecology; 2009, 203 (23), https://doi.org/10.1007/s11258-008-9501-3.

19. Látr, A. M.; Curíková, M.; Baláz, M.; Jurcák, J. Mycorrhizas of Cephalanthera longifolia and Dactylorhiza majalis, two terrestrial orchids. Annales Botanici Fennici; 2008, 45, p 281-289.

20. Леонова, А. А.; Шилова, И. В.; Петрова, Н. А.; Костецкий, О.В.Особенности семенного размножения рябчика русского (Fritillaria ruthenica Wikstr.) в естественных популяциях. Бюллетень Ботанического сада Саратовского госуниверситета; 2016, 14 (1), с 43-48.

21. Бєлан, С. С. Онтогенетична структура популяцій рідкісного виду Gladiolus tenuis на градієнті фенісиціальної дигресії заплавних лук (Сумський геоботанічний округ). Вісник Сумського начіонального аграрного університету. Серія: Агрономія і біологія; 2014, 3, с 20-24.

22. Масленников, А. В.; Масленникова, Л. А.; Пашина, А. А. Современное состояние ценопопуляций ириса борового (Iris pineticula Klok.) в центральной части Приволжской возвышенности. Современные проблемы эволюиии и экологии; 2016, c 393.

23. Чуй, О. В.; Шумська, Н. В. Біометричні параметри генеративних особин Pulsatilla patens (1.) Mill. у ценопопуляціях Західного Поділля. Вісник Черкаського університету. Серія : Біологічні науки; 2014, 36, с 124-128.

24. Косюкова, О. В.; Демочко, Ю. А.; Петрова, Н. А.; Шилова, И. В. Семенное размножение Pulsatilla patens (L.) Mill. и Pulsatilla pratensis (L.) Mill. Бюллетень Ботанического сада Саратовского госуниверситета; 2014, 12, с 110-119.

25. Bochenková, M.; Hejcman, M.; Karlík, P. Effect of plant community on recruitment of Pulsatilla pratensis in dry grassland. Scientia agriculturae bohemica; 2012, 43 (4), p 127-133.

26. Куземко, А. А.; Чеканов, М. М. Екологоценотичні особливості Pulsatilla pratensis (L.) Mill. у 
Науковий вісник Східноєвропейського національного університету імені Лесі Українки. Серія: Біологічні науки, 2019, 4 (388)

Правобережному Лісостепу України. Інтродукція рослин; 2014, 1, с 30-36.

27. Андрієнко, Т. Л. Рідкісні види судинних рослин Українського Полісся. Український ботанічний журнал; 2008, 65 (5), с 666-673.
28. Скляр,
B. Г.;
Злобін,
Ю. А.

Внутрішньопопуляційна структура та методика іiі вивчення у деревних лісоутворюючих видів. Чорноморський ботанічний журнал; 2013, 9 (3), c 316-329.

29. Скляр, В. Г.; Скляр, Ю. Л.; Гудаков, О. О.; Тихонова, О.М. Характеристика природних комплексів Гетьманського національного природного парку. Вісник Сумського національного аграрного університету. Серія «Агрономія $i$ біологія»; 2012, 2 (23), с 13-17.

30. Скляр, В.Г. Природне поновлення дуба звичайного на території Новгород-Сіверського Полісся: поширеність у фітоценозах та диференціація їх умов за ступенем сприятливості для цього процесу. Питання біоіндикації та екологї̈; 2013, 18 (2), с 56-70. 